\title{
Effect of zaï and micro dose on root biomass and the grain and straw yield of sorghum at Tangaye in the North region in Burkina Faso
}

\author{
Albert BARRO ${ }^{1 *}$, Souleymane SANKARA ${ }^{2}$, Clarisse Pulchérie \\ $\mathrm{KONDOMBO}^{3}$
}

\author{
${ }^{1}$ INERA, Programme GRN/SP centre, DRREA du centre, BP 10 Koudougou, Burkina Faso. \\ Email : altbarro@yahoo.fr \\ ${ }^{2}$ Laboratoire Dynamiques des Espaces et Sociétés (LDES),Université Ouaga 1 Pr Joseph KIZERBO, Burkina Faso. \\ solosank@yahoo.fr \\ ${ }^{3}$ INERA, Programme CT, DRREA du centre, BP 10 Koudougou, Burkina Faso. \\ clarissebk@yahoo.fr \\ *Corresponding author: altbarro@yahoo.fr; BP 10 Saria/Koudougou;
}

\begin{abstract}
Faced with rainfall variation and the poor performance of farming practices, the North region of Burkina Faso often observed cereal deficits. Sorghum, the main staple food crop in this region, provides relatively low yields $\left(1000 \mathrm{kgha}^{-1}\right)$. Furthermore, in the area, the density of the population is one of the highest in the country. In order to increase sorghum yields, a study has been carried out in the village of Tangaye by combining the water management practice through mechanized and manual zaï techniques with fertilization by microdose of NPK fertilizer. The experimental design of the study was a split-plot with three replications and four treatments set on a crusty bear soil "Zipellé".The mechanized zaï and the manual zai have been compared with and without applying mineral NPK fertilizer by a micro dose. The effects of these techniques have been evaluated on the soil and the root system by the method of taking monoliths. The grain and straw yields of sorghum have been evaluated for each treatment. The results showed that the greatest roots system development was obtained on the mechanized zaï plot with the application of micro dose of NPK fertilizer. This treatment also has the highest grain yield (2910 $\left.\mathrm{kgha}^{-1}\right)$ compared to manual Zä (1620 $\left.\mathrm{k} \mathrm{ha}^{-1}\right)$ Keywords - Soil tillage, manual and mechanized Zaï, sorghum, root, yield.
\end{abstract}

\section{INTRODUCTION}

Agricultural production in Burkina Faso is dominated by cereals (sorghum, millet, maize, rice and fonio), which cover $69.9 \%$ of the area devoted to food crops. The physical and sufficient availability of food cereals to meet the needs of populations remains a challenge for agricultural policies. Among food cereals, sorghum, [Sorghum bicolor (L.) Moench] is the most widely used in Burkina Faso. Its cultivation covers 1.73 million hectares, which represent $43.2 \%$ of cereal areas and $30.2 \%$ of crop production areas (MAAH, 2016). Most of sorghum-based cropping systems are extensive. The increase in grain production is more related to that of the areas. In 2016, the sorghum growing areas were increased up to $7.6 \%$ with regard to the average of the past five years, with an average increase of $3.5 \%$ in grain production, showing the extensive character of the production (MAAH, 2016).

In the North region of Burkina Faso, situated in the Subsahelian zone between 500 and $700 \mathrm{~mm}$ of rainfall, $95 \%$ of the population depend on agriculture and livestock. Cereal productivity is low. Among the main reasons of the low productivity are the rainfall constraints, the physical and chemical degradation of soils and the inadequacy of cultural practices (Bado, 2002). Thus, a large proportion of rural households regularly live in food insecurity (MAAH, 2016). A study conducted in Burkina Faso showed that food security improves when households depend on their own production (Thiombiano et al., 2014). In 2016, in the North region, cereal production losses due to drought were estimated at 104,466 tons which represent $15.6 \%$ of losses of all the 13 regions of Burkina Faso.

Nicou et al. (1987), Zougmoréet al.(2002), Barro et al. (2005) showed in Burkina Faso that water management techniques combined with fertilization allowed to have high yields in farmer's fields. Palé et al. (2009) have also shown that scarification associated with mineral fertilization by micro-dose leads to increase sorghum grain yields of 25\%. Dimtsu et al. (2018) reported in Ethiopia that soil degradation has an impact on crop productivity. 
Studies conducted in Zondoma province in the North region showed that the phenomenon of soil degradation in this province slowed down but not stopped (PDCL, 2007). To improve the productivity of degraded soils and increase sorghum productivity, a study was conducted in the village of Tangaye located in Zondoma province to assess the effect of water management techniques using manual and mechanized zaï and micro dose of fertilizer (NPK) on the development of sorghum root system, as well as on grain and straw yields.

\section{MATERIAL AND METHODS}

\subsection{The study site}

The study was conducted in Sub-sahelian zone (isohyet 600-700 mm), in the village of TangayeFig. 1),Zondoma province in the North region of Burkina Faso. Tangaye is located at $15 \mathrm{~km}$ East of Gourcy, at $13^{\circ} 33{ }^{\prime} \mathrm{N}$ and $2^{\circ} 33^{\prime} \mathrm{W}$ with an altitude of $338 \mathrm{~m}$. The rainfall is characterized by a strong interannual variation. The climate is Sahelosoudanian with two seasons: a long dry season from November to June alternating with a rainy season from July to October (Fontes andGuinko, 1995; Kaboré, 2013).
The average annual rainfall over the last 30 years has been $650 \mathrm{~mm}$.

The natural vegetation is significantly degraded by human activities (demographic and land pressure, etc.)combined to climate change (droughts and floods). The most common species are: Khaya senegalensis, Annogeissus leiocarpus, Acacia penata, Mitragyna inermis, Tamarindus indica, Ficus sp., Accacia ssp., Combretum ssp., Butirospermum paradoxum, Guiera senegalensis, Boscia senegalensis, Zizyphus mauritiana and Piliostigma ssp. Theherbaceous layer mainly includes Pennisetum pedicellatum, Schoenfeldia gracilis, Loudecia togoensis and Andropogon Sp.(Fonte andGuinko, 1995).

Most of the soils are lixisoil types on gravels (FAO, 2006). This type of soil represents $26.2 \%$ of the country's areas (Zougmoré andBarro, 2002). They are poor in mineral nutrients; their depth and water reserve are low; in the case of high population density like Tangayethese soils are exploited. The soils of Tangaye are particularly exposed to water erosion because of their physical characteristics (sensitive structures and textures favoring encrusting, low organic matter content) and the length of the slopes (sometimes greater than $2 \mathrm{~km}$ ) (Roose, 1981).

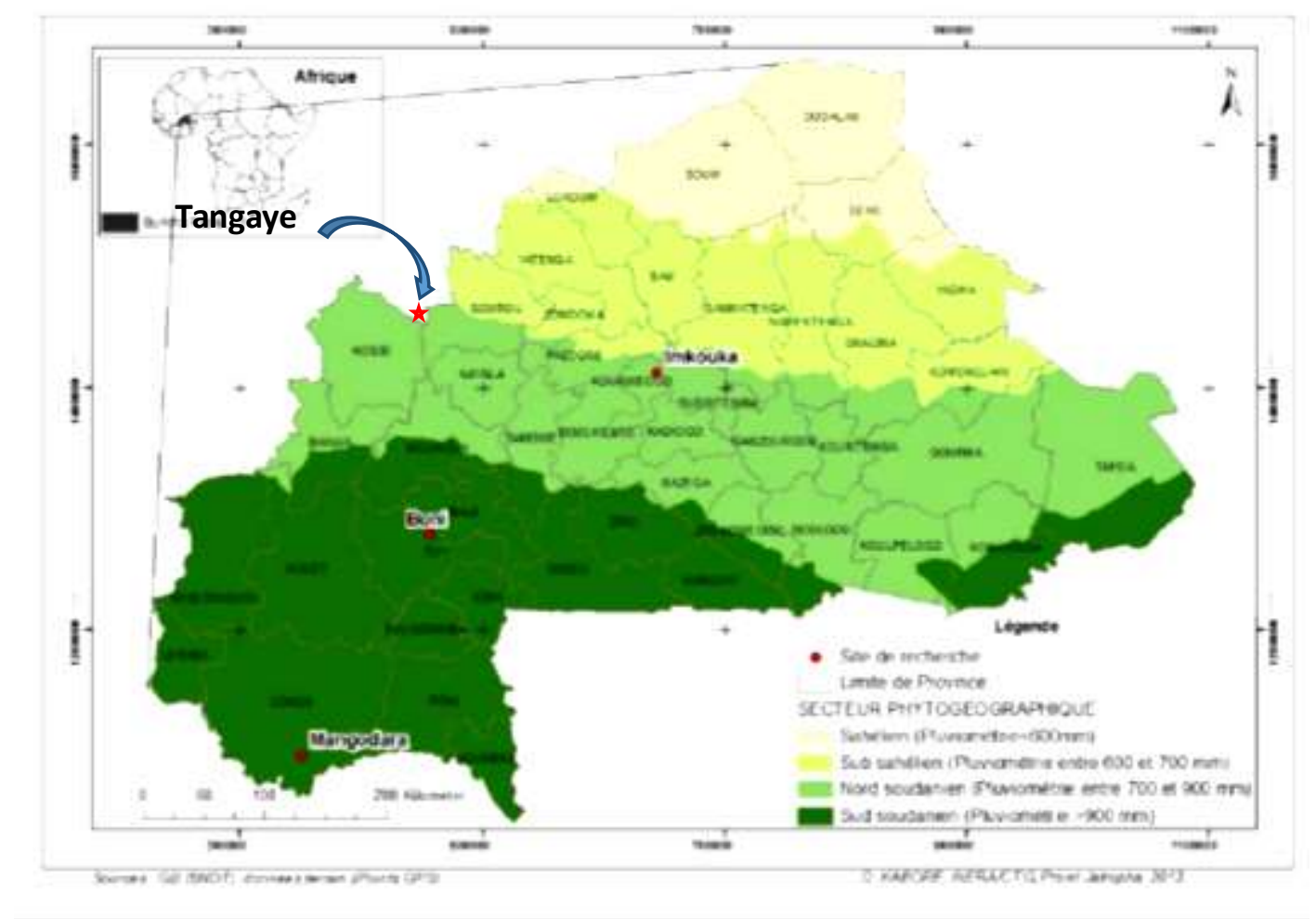

Fig. 1: Location of the study site in Burkina Faso

\subsection{Plant material}

The plant material used in this study was sorghum, the Kapèlga (SCHV 168) variety. Kapèlga belong toguinea botanical race, an improved local sorghum variety released by INERA sorghum program. This sorghum is particularly interesting for its white grain, its short cycle duration (90 days) and it's good vitreous grain well suited to local dishes. Kapèlga is largely cultivated in many areas, even in the humid zones of Burkina Faso (900-1000 $\mathrm{mm})$.

\subsection{Experimental design}

The experimental plots were set on a crusty bear soil "Zipellé". Thedesignwas a split plotwith two factors 
studied in three replications. The main factor was the soil tillage with two modalities: mechanizedzaï andmanual zaï. The secondary factor was fertilization with two modalities: the application of the microdose of NPK fertilizer and the no-application of the micro-dose. The manual and mechanized zaï practices were carried out in dry soil conditions before the beginning of rainy season2016.The plots of soil tillagewere $14 \mathrm{~m}$ long and 10 $\mathrm{m}$ wide. The sowing was carried out on $3^{\text {rd }}$ July 2016.

The soil tillage modalities:

- The mechanized zaï was carried out with twooxenhitch with $80 \mathrm{~cm}$ between the rows and 40 $\mathrm{cm}$ between the seed holes.

- The manual zaï was carried out manually with a hoewith $80 \mathrm{~cm}$ between rows and $40 \mathrm{~cm}$ betweenthe seed holes. The seed holes were arranged in staggered from row to row.

For each seed hole ofmanual ormechanizedzaï, the quantity of compost applied was $300 \mathrm{~g}$ that mean 9.375 tha ${ }^{-1}$. The thinning was carried out with two plants for each seed holes.

The fertilizationmodalities:

- The application of the micro dose of NPK (1423-14, 6S-1B) was carried out on the plots of manualand mechanized zaï 3 weeks after the sowing. The dose applied was $2 \mathrm{~g} / \mathrm{seed}$ hole at 2 $3 \mathrm{~cm}$ upslope from the seed hole and at 2 or $3 \mathrm{~cm}$ deep. This corresponds to $62.3 \mathrm{kgha}^{-1} \mathrm{of}$ NPKfertilizer.

- The treatmentwithout applying fertilizerby micro dose:there was not application of micro dose of NPK fertilizeron the plots ofmanualandmechanizedzaï.

\subsection{Data collection and analysis}

- The soil resistance topenetration

The soil resistance to penetrationwas measured withthe percussion cone penetrometeron theplots at the beginning of therainy season with $5.3 \%$ of soil moisture.

- The soil moisture

The soil moisture was measured on theplots $31^{\text {st July }(28}$ days after sowing) and $29^{\text {th }}$ September( 88 days after sowing) from 0 to $60 \mathrm{~cm}$ deep at each $10 \mathrm{~cm}$.

\section{- The rootbiomass}

The rootbiomasswasevaluated by the method of takingmonolithswith three-side box(Chopart andSiband, 1999). The weight of the roots was measured after washing the earth of the monoliths.The measurements were carried out atsorghumflowering stage.Threerepetitionswerecarried out for eachplotin the layers $0-20 \mathrm{~cm}$ and $20-40 \mathrm{~cm}$. The dry weight of the sorghum rootsis then measured afterstove drying.

- The grain and strawyields

The grain and strawyields were calculated from the grain and straw dry weight. The data were analyzed withXLSTAT software version 2016.02.27444 by the ANOVAmodule.The means comparison was carried out by Newman and Keuls test at $\alpha=0.05$.

\section{RESULTS}

3.1 Chemical and physical characteristics of plot soil The chemical characteristics of experimental soil showed a low content of nitrogen $(\mathrm{N})$ and organic matter (table 1). Granulometric analysis showed in the first 20 centimeters that the soil is a sandy-loam (US textural classification), (table 2). This soil is rather sensitive to erosion due to its high level of silt and fine sand content. With such a texture made up of $74.5 \%$ of sand and fine sand, the soil resistance to penetration cannot be high.

Table 1:Some chemicalcharacteristicsofthe experimentation soil

\begin{tabular}{ccccccccc}
\hline $\mathbf{p H}$ H20 & $\mathbf{p H}$ kcl & $\begin{array}{c}\text { Carbon } \\
(\boldsymbol{\%})\end{array}$ & $\begin{array}{c}\mathbf{O M} \\
(\boldsymbol{\%})\end{array}$ & $\begin{array}{c}\mathbf{N} \\
(\boldsymbol{\%})\end{array}$ & $\mathbf{C} / \mathbf{N}$ & $\begin{array}{c}\mathbf{P}_{-} \text {total } \\
(\mathbf{m g} / \mathbf{k g})\end{array}$ & $\mathbf{P}_{-}$available $(\mathbf{m g} / \mathbf{k g})$ & $\begin{array}{c}\mathbf{K} \\
(\mathbf{m g} / \mathbf{k g})\end{array}$ \\
\hline 5.7 & 4.7 & 0.43 & 0.74 & 0.05 & 9 & 70.00 & 0.43 & 0.30 \\
\hline
\end{tabular}

Legend: OM: Organic matter, N: nitrogen; P phosphorus; K: potassium

Table.2: Experimentation soiltexture $(0-20 \mathrm{~cm})$

\begin{tabular}{cccccc}
\hline Fractions & Loam & Fine silts & Coarse Silts & Fine Sand & Coarse Sand \\
\hline Rate $(\%)$ & 10.8 & 6.3 & 14.9 & 46.8 & 21.4 \\
\hline
\end{tabular}

\subsection{The soil resistance to penetration}

Fig. 2 shows the variation insoil resistance to penetration depending onthe depth. The profiles of the soil resistance to penetration (1, 2and 3) show a weak valueon the layer0-15 $\mathrm{cm}$. This resistance increases quickly to reach 800 to 1000 (Pa)around $25 \mathrm{~cm}$ deep. Only the profile 4shows that resistances of $500 \mathrm{~Pa}$ can be reached in the first $5 \mathrm{~cm}$ layer. 
$\longrightarrow$ Profile-1 Profile-2 Profile-3 Profile-4

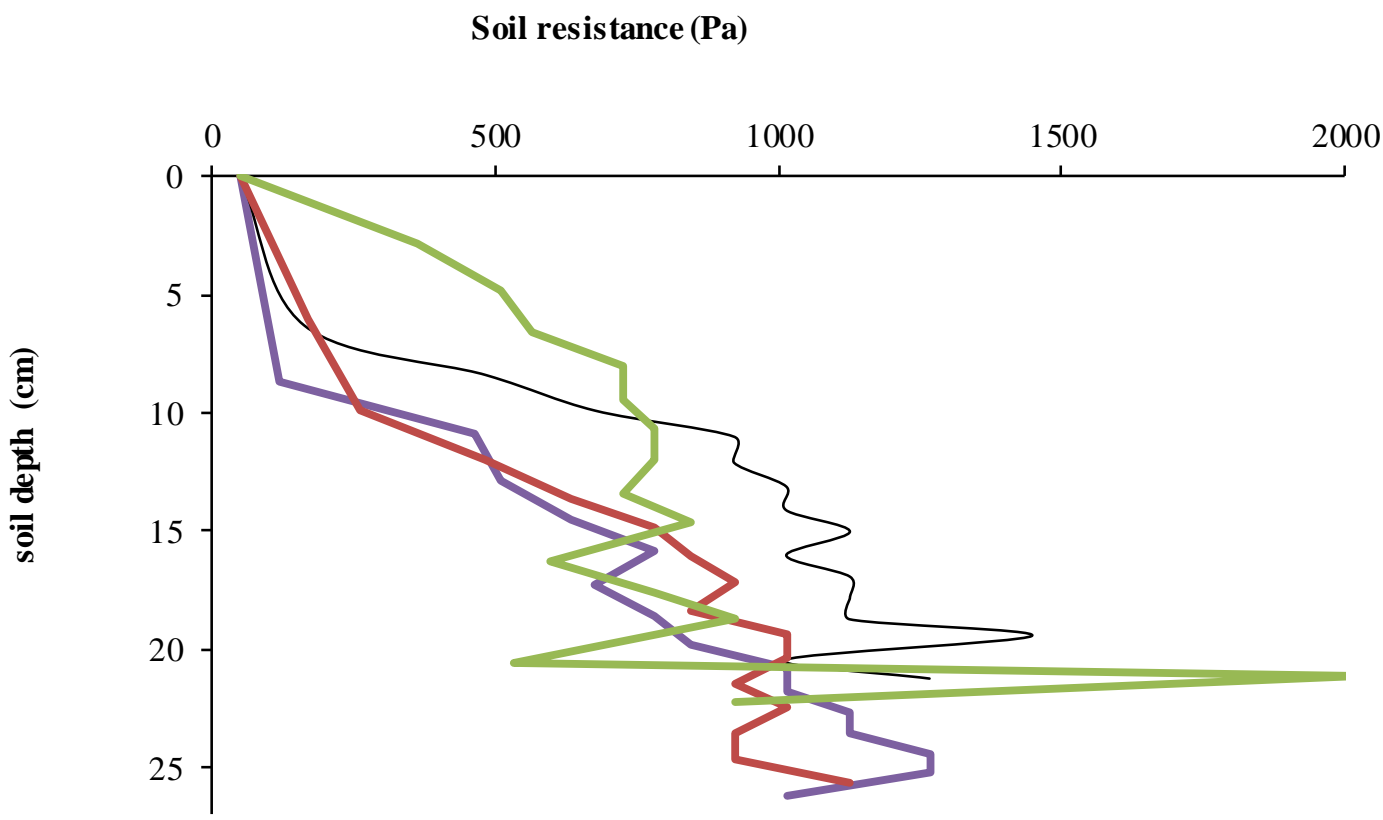

Fig.2:Variation of the soil resistance to penetration atthe beginning of the cropping season

\subsection{Zaï holes sizes}

The ANOVA on the sizes of the holes of manual and mechanized zaï in the plots showed that there is no statistical difference between them(table 3).

Table.3:Sizes of zaïholes

\begin{tabular}{lcc}
\hline Soil tillage & $\begin{array}{c}\text { Depth } \\
(\mathbf{c m})\end{array}$ & $\begin{array}{c}\text { Wide } \\
(\mathbf{c m})\end{array}$ \\
\hline Mechanized zaï & 10.8 & 35.2 \\
Manual zaï & 10.1 & 36.0 \\
\hline Probability & 0.23 & 0.52 \\
Signification & $\mathrm{NS}$ & $\mathrm{NS}$ \\
\hline
\end{tabular}

Legend: NS:Not-significant

\subsection{Soil moisture}

The ANOVA on the soil moisture at the beginning and at the end of plants cycle showed a highly significant difference between the two dates of the measurement $\left(31^{\text {st }}\right.$ July and $29^{\text {th }}$ September). The interaction between dates and soil depths is also significant (table 4). On $31^{\text {st July }}$ (28 days after seedlings), the soil moisture is high on all plots. It varies from 14.5 to $17.3 \%$ in the first $20 \mathrm{~cm}$ layer.On $29^{\text {th }}$ Septemberat the end of the plants cycle, the soil moisture is low in the first $20 \mathrm{~cm}$ layer (10.1 to $10.5 \%$ ); but between 20 and $60 \mathrm{~cm} \mathrm{depth,} \mathrm{it} \mathrm{remains} \mathrm{as}$

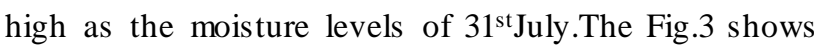
the soil moisture variation between the two dates.

Table.4: Probabilities from ANOVA on the soil moisture

\begin{tabular}{lcr}
\hline Source & DDL & $\begin{array}{c}\text { Probability } \\
\text { (soil moisture) }\end{array}$ \\
\hline Date & 1 & 0.009 \\
Soil tillage & 1 & 0.677 \\
depth & 5 & 0.018 \\
Date* soil tillage & 1 & 0.986
\end{tabular}




\begin{tabular}{lrr} 
Date * depth & 5 & 0.032 \\
Soil tillage $*$ depth & 5 & 0.364 \\
\hline CV $(\%)$ & & 17.3 \\
\hline
\end{tabular}

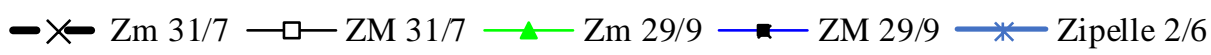

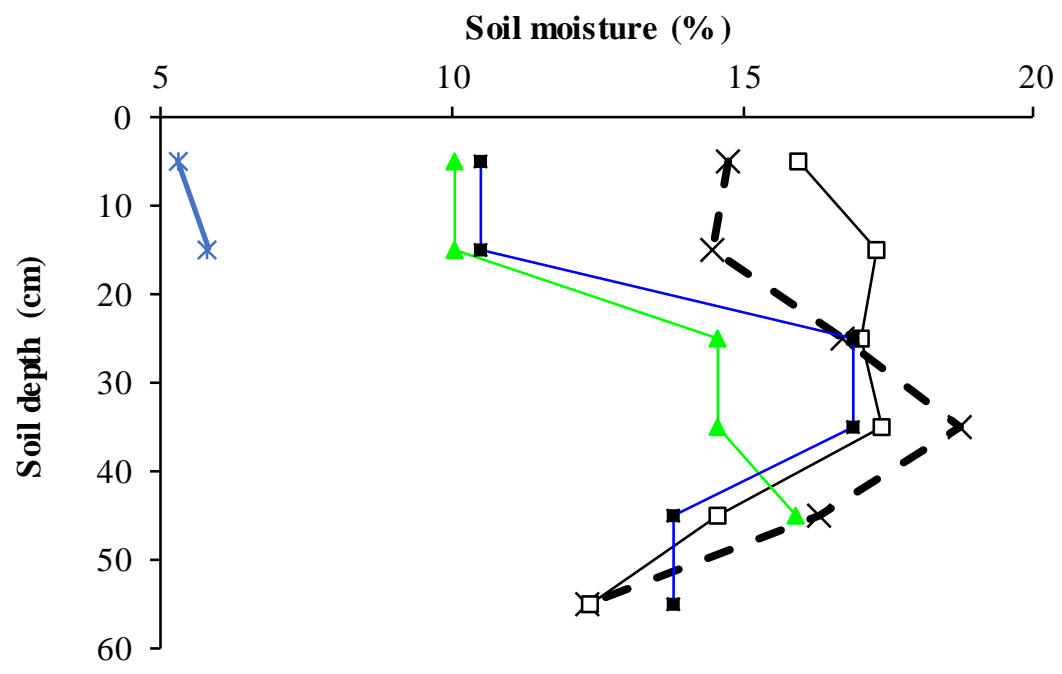

Fig. 3: Soil moisture variation on the zaïplots

Legend:Zm:manual zaï; ZM:mechanized zaï; zipellé:control

\subsection{Sorghum root biomass}

The ANOVA showed a highly significant difference for the root biomass between the soil tillage practices. The differences were also highly significant for mineral fertilizer as well as its interaction with soil tillage (table 5).Regarding the dry weight of sorghum roots per hectare in the soil layer $0-20 \mathrm{~cm}$ and $20-40 \mathrm{~cm}$, there was a significant difference between treatments. The highest root biomass was provided by the mechanized zaï treatments with micro dose or not, but, for manual zaï the micro dose led to increase root biomass (Fig.4).

\subsection{Sorghum grain and straw yields}

The results of ANOVA on sorghum grain yield were highly significant for soil tillage as formineral fertilizer (table 5).The difference between the treatments of mechanized zaï and manual zaï was very highly significant with a probability of 0.001 ; the same trend was observed between the treatments with application of micro dose and without micro dose with a probability of 0.000 . The mechanized zaï with micro dose leads to an increase of sorghum grain yield of $+89.8 \%$ compared to manual zaï with the micro dose. Regarding the mechanized zaï without micro dose, it leads to sorghum grain yield gain of $+79.6 \%$ compared to manual zaï without the micro dose .For the mechanized zaï the application of fertilizer by micro dose gave an average grain yield of $2910 \mathrm{kgha}^{-1}+114.7 \%$ compared to mechanized zaï without micro dose). For the manual zaï the application of fertilizer by micro dose gave an average grain yield of $1620 \mathrm{~kg} \cdot \mathrm{ha}^{-1}(+126.9 \%$ compared to manual zaï without micro dose), (Fig.5). Regarding the straw yield, there was no statistical difference between the treatments. The yields have varied from 3413 to 6225 kg.ha-1 (Fig 6).

Table.5:Probabilities from the varianceanalysison the rootbiomass, grain and strawyields

\begin{tabular}{lrrrr}
\hline Source & DDL & \multicolumn{1}{c}{ Roots biomass } & \multicolumn{1}{c}{ Grains yield } & \multicolumn{1}{c}{ Straw yield } \\
\hline Soil tillage & 1 & $<0.0001$ & 0.001 & 0.704 \\
Fertilizer & 1 & 0.004 & 0.000 & 0.087 \\
Soil tillage * Fertilizer & 1 & 0.003 & 0.078 & 0.658 \\
\hline CV $(\%)$ & & 21.6 & 50.6 & 39.0 \\
\hline
\end{tabular}


$\square 0-20 \mathrm{~cm} \square 20-40 \mathrm{~cm}$

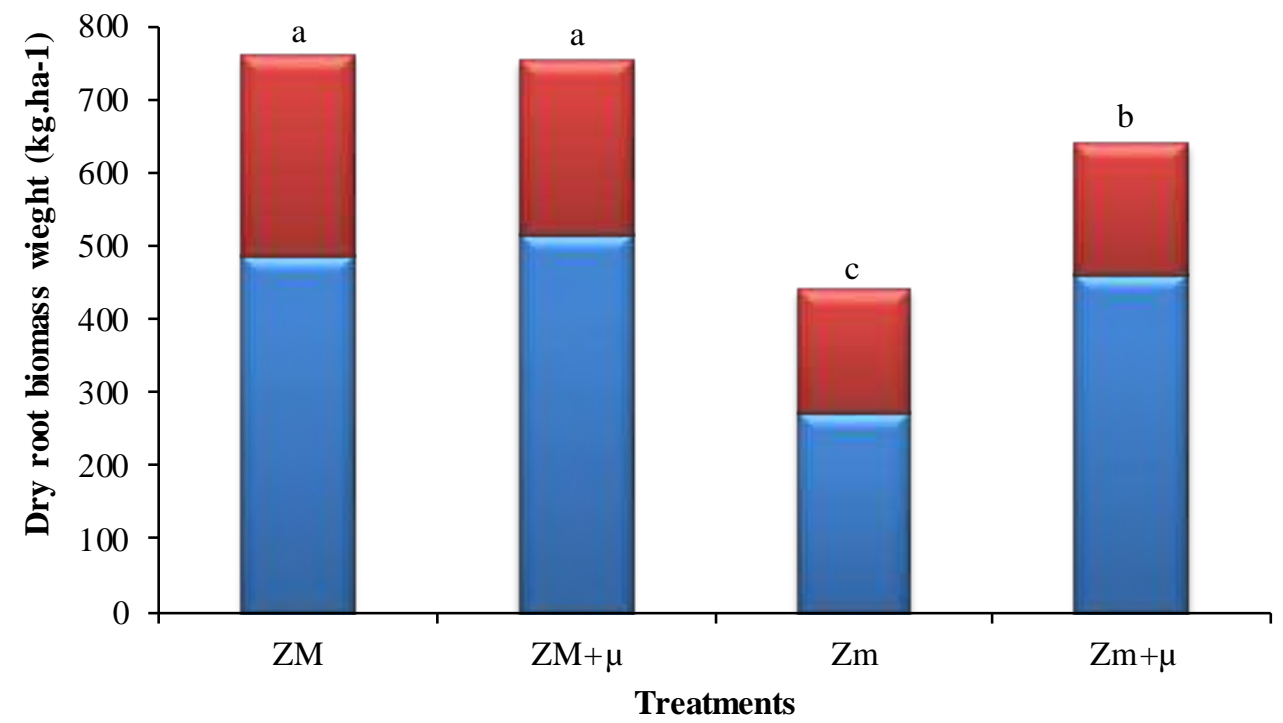

Fig. 4: Sorghum roots biomass in two layers of soil

Legend: ZM: mechanized zaï; Mm: manual zaï; $\mu$ : micro dose of NPK

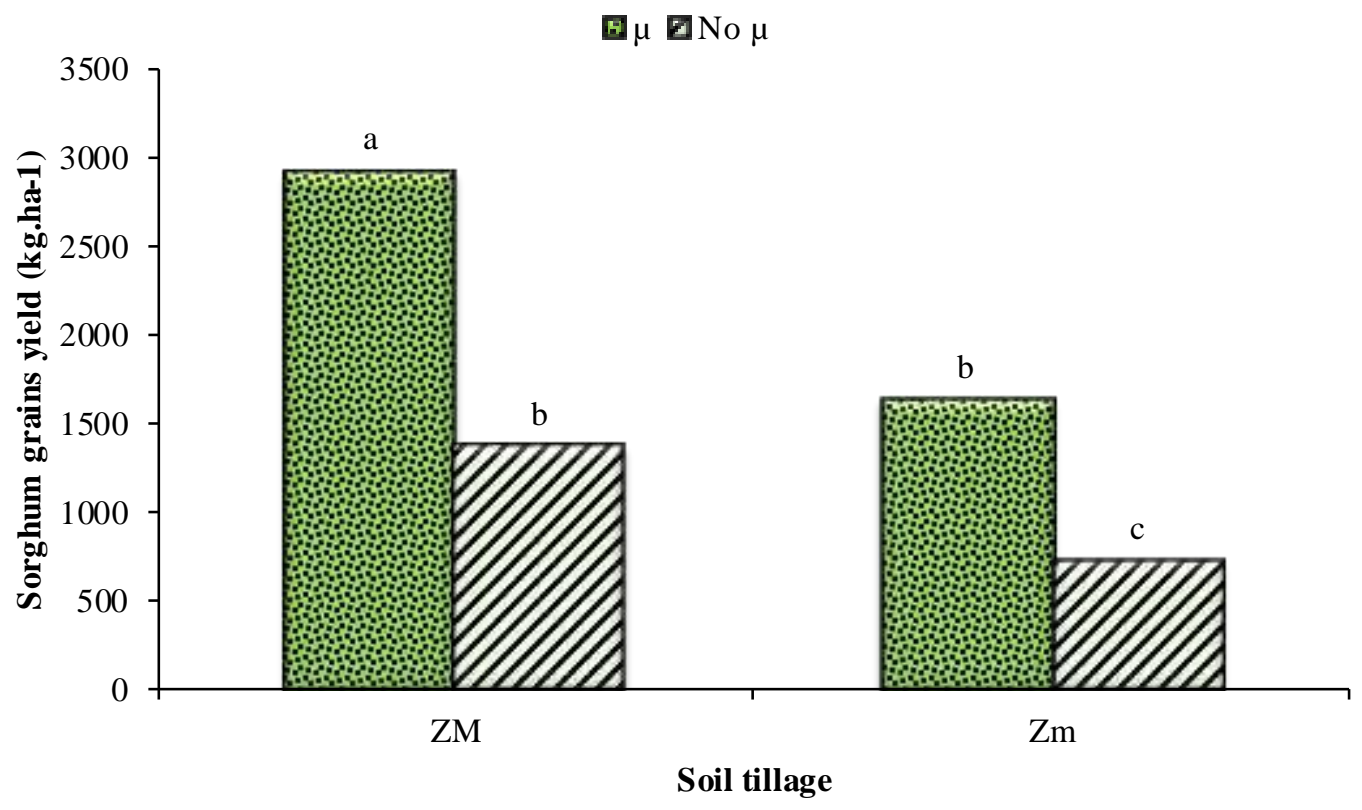

Fig. 5: Sorghum grains yields comparison

Legend: ZM:mechanized zaï; Zm: manual zaï; $\mu$ : micro dose of NPK 


\section{血 $\mu$ 曰No $\mu$}

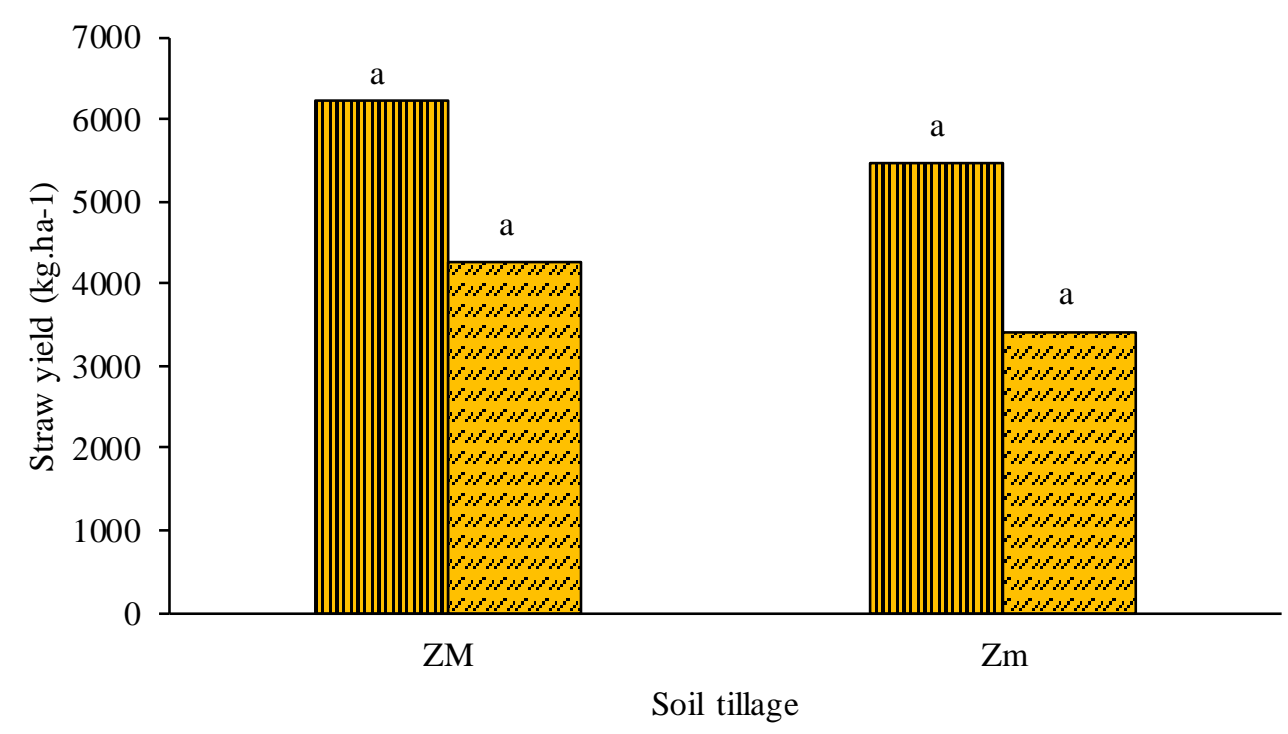

Fig. 6: Sorghum straw yield

Legend: M: mechanized zä̈; Mm: manual zä̈; $\mu$ : micro dose of NPK

IV.

\section{DISCUSSION}

The depths and widths of the mechanized zaï holes and those of the manual zaï in this study were the same. Indeed, this soil was of low resistance to penetration and the operators of the realization of the manual zai did not have trouble during holes digging. In the first $6 \mathrm{~cm}$ on this site, the soil resistance to penetration was on average 202 $\mathrm{Pa}$. At $10 \mathrm{~cm}$ depth the soil resistance to penetration was $524 \mathrm{~Pa}$. The holes were $10.8 \mathrm{~cm}$ for the mechanized zai and $10.1 \mathrm{~cm}$ for the manual zaii. Hole digging was done in the area of low soil resistance to penetration. The low soil resistance to penetration can be explained in part by the high soil sand content of the site $(68 \%)$ (Table 2$)$. This "zipelle" type of soil is less resistant to penetration compared to that found by Barro et al. (2005) atPougyango (in the Passore province) where the penetration resistance was $500 \mathrm{~Pa}$ in the first $5 \mathrm{~cm}$, showing the differences between "zipellé"typeof soil.

The higher soil moisture on the plots on July 31 is explained by the fact that it was the beginning of the rainy season,r ainfall was important while plant water requirements were not yet raised. The cumulative rainfall at that time was $257 \mathrm{~mm}$ against $172 \mathrm{~mm}$ in normal years of rainfall. The water demand of the plants increased gradually until the end of their cycle at the end of September corresponding to the period of the end of the rainy season in the study site. Six (6) $\mathrm{mm}$ of rain was received seven days before soil moisture measurement (September 29), explaining the reduction of soil moisture in the $0-20 \mathrm{~cm}$ layer (10.1 to $10.5 \%$ ), while the moisture in the $20-40 \mathrm{~cm}$ layer remained high (15.0 to $17.0 \%)$. The fact that the soil moisture in the $20-40 \mathrm{~cm}$ layer for the mechanized zaï was greater than that of the manual zaï could be explained by the reaction of the dry soil during the action of the tool that breaks while creating cracks that allow the infiltration of water and also the effectiveness of the dry soil preparation tool in improving soil moisture, such as the ripper used by Ayad et al. (2018).

The manual zaï plot with the micro dose produces more root biomass than the one that did not receive the micro dose. This is linked to the supply of NPK mineral fertilizers which contains 23 units of phosphorus (14.26 $\mathrm{kg} \mathrm{ha}^{-1}$ ). Mollier et al. (1999) showed that phosphorus is a favorable nutrient for the development of the maize root system. Mohammed et al. (2018) found that $5.72 \mathrm{~g} \mathrm{~kg}^{-1}$ of $\mathrm{P}$ in soil induced high yield with wheat. The low level of phosphorus in soils is one of the major constraints of production in Burkina Faso (Compaoré et al., 2003; Bonziet al., 2011). Hien (2004) showed that compost had a low level of phosphorus. For manual zaï plots, the applied of the micro dose of NPK fertilizer increases roots biomass by $68 \%$. This increase the ability of plants in these plots to get nutrients. For mechanized zaï plots in the $0-20 \mathrm{~cm}$ layer, the difference between the root biomass of the two plots is smaller. The intake of micro dose of fertilizer only leads to an increase of $5 \%$. This can be explained in part by the action of the tool during dry tillage which by creating cracks in the soil and reduces its resistance to penetration consequently promoting the development of the root system. In the $0-40 \mathrm{~cm}$ layer, the highest root biomass was ranged from 620 to $760 \mathrm{~kg} \mathrm{ha}^{-1}$. This is a parameter of soil fertility sustainability for the 
following years because the roots contain NPK mineral nutrients because Myers (1980).

For grain yield, the plot of mechanized zaï with micro dose supply had almost double the yield of the same plot without micro dose (Fig. 5). This was due to nutrients brought by fertilization by micro dose including phosphorus which is also important in fruiting. This is in line with IDRC's 2014 results in Burkina Faso, where micro-dose intake has led to increased grain yield of sorghum. The decrease in soil resistance to penetration has led to an increase in the amount of root in the soil. With a good moistening of the soil the contribution of the micro dose lead to a high grain yield on the plots. Moreover, the production of manual zaï with micro dose is in the same order as that of the mechanized zai plot without micro dose. The mechanical action of the tool used for mechanized zaï on the ground, generates a yield equivalent to the same yield as that obtained with a micro dose. The straw yields, although having the same tendencies, are not statistically different (Fig. 6).

\section{CONCLUSION}

Mechanized zaï and micro dose of NKP fertilizer gave high level of root biomass on sorghum (760 kg ha-1 in the layer $0-40 \mathrm{~cm}$ ). This roots system is favorable to sorghum nutrient and water uptake.The root system development on thesesplots providesa potential for sustainable production, because the organic matter of the roots will evolve in the soil to improve its structure and enrich its nutrients content. The practice of sorghum cropping by themechanizedzai combined with the application of mineral NPK fertilizerby micro doseshowed a great potential of sorghum yield increase ( $+238 \%$ compared with mechanized zaï without mineral fertilizer).

\section{ACKNOWLEDGEMENTS}

We thank colleagues from the Sustainable Rural Development Program (PDRD) and the provincial Staff of the Zondoma Ministry of Agriculture department for their support during the fieldwork.

\section{REFERENCES}

[1] ALkhafajiAyad combined tillage equipment and it's effect on soil properties. International Journal of Environment, Agriculture and Biotechnology (IJEAB), Vol-3, Issue-3, May-June- 2018. http://dx.doi.org/10.22161/ijeab/3.3.12 ISSN : 24561878

[2] Bado BV. (2002). Rôle des légumineuses sur la fertilité des sols ferrugineux tropicaux des zones guinéenne et soudanienne du Burkina Faso. Thèse de Doctorat, Université Laval, département des sols et de génie agroalimentaire, Québec, Canada, 197 p

[3] Barro A, Zougmoré R and Taonda SJB. (2005). Mécanisation de la technique du zaï manuel en zone semi-aride. Cahiers Agricultures, 14(6) :549-559. DOI : http://revues.cirad.fr/index.php/cahiers agricultures/article/viewFile/30550/30310

[4] Bonzi M, Lompo F, Ouandaogo N, Sédogo PM. (2011). Promoting Uses of indigenous Phosphate Rock for Soil Fertility Recapitalization in the Sahel: state of knowledge on the review of the Rock phosphates of Burkina Faso. In Innovations as key to the green revolution in Africa. Eds A. Bationo et al. vol 1381-390. Springer Science +Business Media BV. DOI 10. 1007/978-90-481-2543-2_39

[5] Chopart JL and Siband P. (1999). Develepment and validation of a model to describe root length density of maize from root counts on soil profiles. Plant and soil 00: $1-14$

[6] Compaoré E, Frossard E, Sinaj S, Fardeau J-C andMorel J-L. (2003). Influence of Land-Use Management on Isotopically Exchangeable Phosphate in Soils from Burkina Faso. Common Ground Sci Anal Seed 34 (1\&2) 201-223 | Published online: 24 Jun 2011 https://doi.org/10.1081/CSS12001742

[7] CRDI. (2014). Integrated nutrient and water management for sustainable food production in the Sahel. Final Technical Report 2014. 28 p.

[8] DGESS (Direction Générale des Etudes et des Statistiques Sectorielles). (2014). Annuaire des statistiques agricoles 2012. Ministère de l'agriculture du Burkina Faso. 227 p.

[9] Dimtsu GY, Mulubrehan Kifle M, Girmay Darcha G. (2018). Effect of soil and water conservation on rehabilitation of degraded lands and crop productivity in Maego watershed, North Ethiopia. Journal of Degraded and Mining Lands Management. $\quad 5(3)$ : 1191-1205. DOI:10.15243/jdmlm.2018.053.1191.

[10] FAO (Agriculture Organization of the United Nations). (2006). World reference base for soil resources: a framework for international classification, correlation and communication. Edt. 2006. Rome. www.fao.org/3/a-a0510e.pdf.

[11] FAO (Agriculture Organization of the United Nations). (2008). Guide de formulation d'une stratégie de mécanisation agricole Etude de cas: stratégie nationale de la mécanisation agricole au Mali Rome. DOI: http://www.fao.org/ag/ags/index_fr.html

[12] Fontes J and Guinko S. (1995). Carte de la végétation et de l'occupation du sol du Burkina 
Faso. Note explicative. Ministère de la coopération française, Toulouse, France

[13] Hien E. (2004). Dynamique du carbone dans un Acrisol ferrique du Centre Ouest Burkina : Influence des pratiques culturales sur le stock et la qualité de la matière organique. Thèse de Doctorat, ENSA Montpellier, $138 \mathrm{p}$.

[14] MAAH (Ministère de l'Agriculture et des Aménagements Hydrauliques).(2016).Résultats définitifs de la campagne agricole et de la situation alimentaire et nutritionnelle 2015/2016, 78 p

[15] Mohammed Zia Uddin Kamal, Md. Dhin Islam, Md. Yunus Miah and Mohammad Saiful Alam. 2018. Yields gap evaluation of wheat grown in Piedmont plain and Floodplain soils of Bangladesh through compositional nutrient diagnosis (CND) norm. International Journal of Environment, Agriculture and Biotechnology (IJEAB), Vol-3, Issue-5, SeptOct- $2018 \quad \mathrm{http} / / / \mathrm{dx}$.doi.org/10.22161/ijeab/3.5.5 ISSN: $2456-1878$

[16] Mollier A and Pellerin S. (1999). Maize root system growth and development as influenced by phosphorus deficiency. Journal of Experimental Botany, Vol. 50, No. 333, pp. 487-497

[17] Myers RJK. (1980). The root system of a grain sorghum crop. Field CropsResearch. Volume 3, 1980, Pages 53-64

[18] Nicou R, Ouattara B et Somé L. (1987). Effets des techniques d'économie de l'eau à la parcelle sur les cultures céréalières (sorgho, maïs et mil) au Burkina Faso. INERA, Burkina Faso, 77 p.

[19] Palé S, Mason SC and Taonda SJB. (2009). Water and fertilizer influence on yield of grain sorghum varieties produced in Burkina Faso. S. Afr. J. Plant Soil, 26(2). 91-97. DOI : http://dx.doi.org/10.1080/02571862.2009.10639939

[20] Thiombiano T, Bikienga IM, Yaméogo J-C, Kaboré A, Traoré S. (2014). Etude pour l'élaboration d'une stratégie nationale en matière d'intrants et d'équipements agricoles au Burkina Faso. MASA (Ministère de l'Agriculture et de la Sécurité Alimentaire). $115 \mathrm{p}$.

[21] Zougmoré R and Barro A. (2002). Techniques de conservation des eaux et des sols au Burkina Faso. Document de formation des formateurs régionaux de la Sofitex. SOFITEX/INERA Burkina Faso. 95 p.

[22] Zougmoré R, Gnankambary Z, Guillobez S, Stroosnijder L. (2002). Effect of stone rows on soil chemical characteristics under continuous sorghum cropping in semiarid Burkina Faso. Soil \& Tillage Research, 66 : 47-53. http://dx.doi.org/10.1007/s 10705-005-0531-0. 